\title{
DECORATIVE VALUES AND THE NUTRITIONAL STATUS OF SOME Magnolia SPECIES UNDER THE CLIMATIC CONDITIONS OF LUBLIN (POLAND) PART II. EVALUATION OF THE NUTRITIONAL STATUS OF THE PLANTS
}

\author{
Zenia Michałojé, Zbigniew Jarosz, Krzysztof Bartnik, Joanna Konopińska \\ Department of Cultivation and Fertilization of Horticultural Plants, University of Life Sciences in Lublin, \\ Leszczyńskiego 58, 20-068 Lublin, Poland \\ e-mail: zenia.michalojc@up.lublin.pl
}

Received: 10.05.2012

\section{Abstract}

The present study was conducted on six Magnolia species in the period 2006-2008 in the Botanical Garden of the Maria Curie-Skłodowska University in Lublin. The soil and leaves from the locations of the following species of Magnolia were subjected to evaluation: cucumber tree (Magnolia acuminata L.), Kobushi magnolia (Magnolia kobus DC), purple lily magnolia (Magnolia liliiflora L.), Japanese willow-leaf magnolia (Magnolia salicifolia Siebold et Zucc. Maxim.), saucer magnolia (Magnolia x soulangiana Soul.-Bod.), and umbrella magnolia (Magnolia tripetala L.). The studied plants were planted during the period 1968-1989 on grey-brown podzolic soil derived from loess. The significantly lowest content of phosphorus, potassium and magnesium as well as the lowest $\mathrm{pH}$ were recorded in the soil from the location occupied by the purple lily magnolia $(M$. liliiflora). The other sites were characterized by an optimal range of $\mathrm{pH}$, high soil phosphorus and magnesium availability as well as medium potassium availability. An optimal content of nitrogen and calcium was found in the leaves of the cucumber tree (M. acuminata), of phosphorus and magnesium in the leaves of the Kobushi magnolia (M. kobus), and of potassium in the leaves of the Japanese willow-leaf magnolia (M. salicifolia). A low content of nitrogen and calcium was shown in the leaves of the purple lily magnolia (M. liliiflora), of phosphorus in the leaves of the saucer magnolia ( $M . x$ soulangiana), and of potassium in the indicator parts of the cucumber tree (M. acuminata). The study found that among the studied species the cucumber tree ( $M$. acuminata) could be a good biostabilizer of nitrogen, while the Kobushi magnolia (M. kobus) a good biostabilizer of phosphorus and magnesium. In spite of significant differences in soil nutrient availability and clear variations in macronutrient contents in the indicator parts of the investigated plants, no visual symptoms of nutrient deficit were found in the Magnolia species under study.
Key words: Magnolia, six species, leaves, total nitrogen, phosphorus, potassium, calcium, magnesium

\section{INTRODUCTION}

The decorative value of ornamental trees and shrubs hugely depends on proper plant nutrition. According to A e nd e kerk (1997), magnolias are classified as species of low nutritional requirements. In turn, C zekalski (2007) stresses that these plants require fertile and humus-rich sites, since Magnolia develops a relatively shallow root system, which, compared to other species, substantially limits the possibility of these plants to penetrate the soil in search of available forms of nutrients. Moreover, optimal plant nutrition is dependent not only on soil nutrient content, but also on factors determining nutrient availability (Nurzy ński, 2003). In the opinion of Perry and $\mathrm{H} \mathrm{i} \mathrm{c} \mathrm{k} \mathrm{m} \mathrm{an} \mathrm{(2001),} \mathrm{both} \mathrm{visual} \mathrm{assessment} \mathrm{of} \mathrm{the}$ appearance of plants and chemical analysis of the soil can be insufficient to properly diagnose the nutritional status of plants. Kopinga and van den Burg (1995) claim that chemical analysis of the indicator parts of plants is the most accurate method for evaluation of their nutritional status, but the absence of clearly defined limit values representing optimal nutrient contents is still an unresolved problem.

The aim of the present study was to determine the level of supply of essential nutrients to some $M a$ gnolia species in relation to their content in the soil environment and to evaluate the studied plants in terms of the possibility of biostabilization of some elements. 


\section{MATERIALS AND METHODS}

The study was conducted in 2006-2008 on six Magnolia species growing in the Botanical Garden of the Maria Curie-Skłodowska University in Lublin, with the following species selected for the study: tree cucumber (Magnolia acuminata L.), Kobushi magnolia (Magnolia kobus DC), purple lily magnolia ( $\mathrm{Ma}$ gnolia liliiflora L.), Japanese willow-leaf magnolia (Magnolia salicifolia Siebold et Zucc. Maxim.), Soulange's magnolia, syn. saucer magnolia (Magnolia $x$ soulangiana Soul.-Bod.), and umbrella magnolia (Magnolia tripetala L.). The respective plants were planted during the period 1968-1989. Thus, observations and investigations were carried out on magnolia trees in an age range of 22-43 years. The selected magnolia sites are located on grey-brown podzolic soil derived from loess containing 20-35\% of fine particles.

Soil samples for chemical analysis in all the years of the study were collected in the second decade of August. Samples representatives of the individual locations were collected from a depth of $0-20 \mathrm{~cm}$ in accordance with the applicable recommendations. After sampling, the soil was dried and sieved through a $2 \mathrm{~mm}$ mesh sieve. Following extraction of the soil samples in a solution of $0.04 \mathrm{M} \mathrm{Ca}\left(\mathrm{CH}_{3} \mathrm{CHOHCOO}\right)_{2}$ acidified with $\mathrm{HCl}$ to $\mathrm{pH} 3.6$ (Egner-Riehm method), phosphorus was determined in the extract colourimetrically with the molybdate mixture and photorex, while potassium by AAS (Perkin-Elmer, Aanalyst 300). After extraction of the soil samples, magnesium was determined by AAS in $0.0125 \mathrm{M} \mathrm{CaCl}_{2}$ extract (Schatschabel method). In addition, $\mathrm{pH}$ was determined in the soil samples in a solution of $1 \mathrm{M} \mathrm{KCl}$.

Leaf samples of the selected Magnolia species were collected in each year of the study from the current year's long shoots in the third decade of August. The date of leaf sampling was delayed in relation to the recommended date for perennial plants due to the fact that magnolias produce leaves later compared to other deciduous tree species. Leaf samples were initially dried at a temperature of $60-70^{\circ} \mathrm{C}$ and then ground. Next, after they were dried at $105^{\circ} \mathrm{C}$, the following were determined:

- total nitrogen by the Kjeldahl method using the Foss Tecator digestion system.

After dry mineralization of the plant material at $550^{\circ} \mathrm{C}$, the following were determined:

- phosphorus colourimetrically with ammonium-vanadium-molybdate (Thermo, Evolution 300), potassium, calcium, and magnesium by AAS (Ostrowska et al. 1991).

The results were statistically analysed by analysis of variance, using Tukey's test to evaluate the differences at a significance level of $\mathrm{p}=0.05$.

\section{RESULTS AND DISCUSSION}

The decorative value of magnolias, in addition to species- and cultivar-specific traits, largely depends on proper plant nutrition. Nutrient deficiencies cause serious disturbances in the proper development of leaves and flowers as well as they manifest themselves in the form of symptoms deteriorating the decorative values of plants (yellowing, necroses, and deformations). In the opinion of Perry and Hickman (2001), visual assessment of the nutritional status of plants carries a high risk of error and may lead to improper use of fertilizers. This is particularly dangerous when excessive amounts of nitrogen and phosphorus, i.e. elements considered to be soil and groundwater pollutants, are introduced into the environment (P e trovic, 1990; Gil m a n et al. 2000). They also draw attention to the risk of excessive ion accumulation and salinity in the soil environment which are dangerous for plants and are very frequently an effect of the use of excessive amounts of fertilizers ( $\mathrm{H}$ arris et al. 1997). According to Perry and $\mathrm{Hickman}$ (2001), there is a need to determine for ornamental trees and shrubs limit values of nutrient contents that would define proper plant nutrition and they recommend for diagnostic purposes chemical analysis of the indicator parts of plants.

Observations and analysis of the plant material and soil were used to evaluate the nutritional status of the plants. The obtained results clearly show high variation in nutrient content in the plants and soil as well as in soil $\mathrm{pH}$ at the particular study sites (Tables 1 and 2).

The chemical analysis of the soil from the investigated sites of the magnolia trees showed significant variation in $\mathrm{pH}$ as well as in phosphorus, potassium and magnesium content in the root environment of the plants (Table 1). The study also showed substantial differences in soil nutrient availability between years. The highest phosphorus content in all study years was found at the site occupied by the umbrella magnolia (M. tripetala) $-17.6-21.8 \mathrm{mg} \mathrm{P} \times 100 \mathrm{~g}^{-1}$ of soil, while the lowest one in the location occupied by the purple lily magnolia (M. liliiflora) $-0.6-1.4 \mathrm{mg} \mathrm{P} \times 100 \mathrm{~g}^{-1}$ of soil. This relationship is fully reflected in leaf phosphorus content of this magnolia. When the obtained results were compared with the values recommended for the cultivation of ornamental plants ( $\mathrm{K}$ a c p e r s k a et al. 1996; R o s e n et al. 2008), it was found that soil phosphorus availability at the site occupied the purple lily magnolia (M. liliiflora) should be assessed as low, while that in the other locations under investigation as high. These results should be referred to soil $\mathrm{pH}$. At the site occupied by the purple lily magnolia (M. liliiflora), the significantly lowest soil $\mathrm{pH}$ was recorded (4.45-4.82), while the soil in the other studied locations of the magnolia trees was characterized by a slightly acidic or close to neutral $\mathrm{pH}$ (6.05-7.00). 
Such strong soil acidification promotes the chemical sorption of phosphorus which is converted into forms not easily available for plants ( $\mathrm{N} \mathrm{u} \mathrm{r} \mathrm{z} \mathrm{y} \mathrm{ń} \mathrm{s} \mathrm{k} \mathrm{i,} \mathrm{2003;}$ B ruland and Richardson, 2004).

Table 1.

Phosphorus, potassium, magnesium content $\left(\mathrm{mg} \times 100 \mathrm{~g}\right.$ ADW) and $\mathrm{pH}$ level $\left(\mathrm{pH}_{\mathrm{KCl}}\right)$ of soil from the investigated sites of Magnolia $s p$.

\begin{tabular}{|c|c|c|c|c|c|c|c|c|c|c|c|c|c|c|c|}
\hline \multirow{3}{*}{ Sampling site } & \multicolumn{4}{|c|}{$\mathrm{P}$} & \multicolumn{4}{|c|}{$\mathrm{K}$} & \multicolumn{3}{|c|}{$\mathrm{Mg}$} & \multicolumn{4}{|c|}{$\mathrm{pH}_{\mathrm{KCl}}$} \\
\hline & \multicolumn{15}{|c|}{ Year } \\
\hline & 2006 & 2007 & 2008 & $\overline{\mathrm{x}}$ & 2006 & 2007 & 2008 & $\overline{\mathrm{x}}$ & 2006 & 20072008 & $\overline{\mathrm{x}}$ & 2006 & 2007 & 2008 & $\overline{\mathrm{x}}$ \\
\hline Magnolia acuminata & 12.4 & 13.5 & 10.8 & 12.2 & 24.6 & 21.2 & 21.8 & 22.5 & 16.7 & 14.413 .1 & 14.7 & 6.05 & $6 . .35$ & $6 . .30$ & $6.05-6.35$ \\
\hline Magnolia kobus & 14.5 & 13.9 & 9.4 & 12.6 & 19.2 & 13.4 & 18.7 & 17.1 & 18.3 & 19.216 .1 & 17.8 & 7.00 & 6.95 & 6.60 & $6.60-7.00$ \\
\hline Magnolia liliiflora & 1.2 & 1.4 & 0.6 & 1.05 & 9.4 & 5.9 & 11.6 & 9.1 & 13.1 & $13.2 \quad 9.3$ & 11.8 & 4.80 & 4.82 & 4.45 & $4.45-4.82$ \\
\hline Magnolia salicifolia & 11.5 & 13.0 & 12.2 & 12.3 & 21.1 & 19.4 & 19.3 & 19.9 & 13.3 & $12.6 \quad 12.1$ & 12.7 & 6.80 & 6.75 & 6.70 & $6.70-6.80$ \\
\hline $\begin{array}{l}\text { Magnolia } x \\
\text { soulangiana }\end{array}$ & 11.4 & 10.6 & 15.4 & 12.6 & 17.3 & 18.7 & 15.6 & 17.2 & 15.2 & 16.118 .9 & 16.7 & 6.10 & 6.55 & 6.70 & $6.10-6.70$ \\
\hline Magnolia tripetala & 17.6 & 20.7 & 21.8 & 20.1 & 48.2 & 39.1 & 29.2 & 38.8 & 16.1 & 15.115 .6 & 15.6 & 6.60 & 6.65 & 6.85 & $6.60-6.85$ \\
\hline$\overline{\mathrm{x}}$ & 11.4 & 12.2 & 11.7 & & 23.3 & 19.6 & 19.4 & & 15.4 & $15.1 \quad 14.2$ & & $4.80-7.00$ & $4.82-6.95$ & $4.45-6.85$ & $4.45-7.00$ \\
\hline $\mathrm{LSD}_{0.05}$ site & \multicolumn{4}{|c|}{0.85} & \multicolumn{4}{|c|}{1.32} & \multicolumn{3}{|c|}{0.83} & \multicolumn{4}{|c|}{0.26} \\
\hline year & \multirow{2}{*}{\multicolumn{4}{|c|}{$\begin{array}{c}\text { ns. } \\
1.88\end{array}$}} & \multirow{2}{*}{\multicolumn{4}{|c|}{$\begin{array}{l}0.75 \\
2.89\end{array}$}} & \multirow{2}{*}{\multicolumn{3}{|c|}{$\begin{array}{c}\text { ns. } \\
1.82\end{array}$}} & \multirow{2}{*}{\multicolumn{4}{|c|}{$\begin{array}{c}\text { ns. } \\
0.57\end{array}$}} \\
\hline site $\mathrm{x}$ year & & & & & & & & & & & & & & & \\
\hline
\end{tabular}

ns. - not significant

The highest potassium content was found in the soil sampled from the location occupied the umbrella magnolia (M. tripetala) - 29.2-48.2 $\mathrm{mg} \mathrm{K} \times 100 \mathrm{~g}^{-1}$ of soil, while the lowest one from the site with the purple lily magnolia (M. liliiflora) - on average $9.1 \mathrm{mg} \mathrm{K} \times$ $100 \mathrm{~g}^{-1}$ of soil. Comparing the obtained results with the recommendations in the literature sources ( $\mathrm{K}$ a s p e $\mathrm{r}$ $\mathrm{s} k$ a et al. 1996; R o s e $\mathrm{n}$ et al. 2008), the soil from the locations of the tree cucumber ( $M$. acuminata) and umbrella magnolia $(M$. tripetala) was found to be characterized by high soil potassium availability, the soil from the site of the Kobushi magnolia (M. kobus, M. salicifolia and M. x soulangiana) showed medium potassium availability, while the soil from the location of the purple lily magnolia (M. liliiflora) was characterized by a low content of this nutrient. Variation in potassium soil availability demonstrated in the present study was not reflected in the content of this nutrient in the leaves of the magnolia trees growing at the particular sites. Irrespective of the study year, the significantly highest content of potassium (2.0\% DW) was found in the leaves of Magnolia salicifolia, whereas the lowest content $(0.68 \%$ DW) in the indicator parts of Magnolia acuminata (Table 2). It is worth stressing that the factors determining potassium uptake by plants, in addition to the availability of this nutrient in the soil, include the proportion of clay minerals in the soil as well as the content of calcium and magnesium cations ( $N$ u r z y n ski, 2003; R o s e n et al. 2008). These factors could have modified potassium uptake by the studied plants.
In the literature, there is a lack of reports presenting limit values for potassium supply to magnolias which could facilitate interpretation of the obtained results.

Irrespective of the year, the highest magnesium content was recorded in the root environment of the Kobushi magnolia (M. kobus) - on average $17.8 \mathrm{mg}$ $\mathrm{Mg} \times 100 \mathrm{~g}^{-1}$ of soil, whereas the lowest one at the site of the purple lily magnolia (M. liliiflora) - on average $11.8 \mathrm{mg} \mathrm{Mg} \times 100 \mathrm{~g}^{-1}$ of soil. In spite of significant differences, the obtained results allow the soil from all the locations to be classified in the group of soils with high magnesium availability. According to $\mathrm{K} \mathrm{a} \mathrm{c}$ pe r s k a et al. (1996), magnesium content above $7 \mathrm{mg}$ $\mathrm{Mg} \times 100 \mathrm{~g}^{-1}$ of soil is considered to be high.

Most authors agree that magnolia plants require soil with a pH of 5.0-6.0 (C z e k a l s k i, 2007; H of $\mathrm{m}$ a n, 2010). The presented results prove that soil $\mathrm{pH}$ in the locations of all the Magnolia species under stu$\mathrm{dy}$, except for the purple lily magnolia (M. liliiflora), should be considered to be proper (Table 1). However, some reports clearly show large differences in terms of $\mathrm{pH}$ of the root environment between individual species of Magnolia (R o s e $\mathrm{n}$ et al. 2008). In the opinion of Murphy (2009), Magnolia is a plant that tolerates well a decreased $\mathrm{pH}$ of the root environment and sites with a pH of 4.5-5.5. Whiting et al. (2009) even warn against excessive alkalization of the root environment in the cultivation of magnolias due to the increased risk of the occurrence of chlorosis caused by a deficit of iron and other micronutrients. These 
authors include magnolias in plants with high susceptibility to iron deficit, at the same time emphasizing that this adverse phenomenon substantially deteriorates the decorative value of plants.

The present study on the chemical composition of the leaves of some Magnolia species showed significant variation in this composition, depending on the species and year (Table 2). The highest total nitrogen content was shown in the leaves of the cucumber tree (M. acuminata) $-2.40 \%$ of $\mathrm{N}$-total, and the lowest one in the leaves of the purple lily magnolia (M. liliiflora) $-1.54 \%$ of $\mathrm{N}$-total. Analysing nitrogen content in
25 deciduous tree species at different sites, in the case of Magnolia grandiflora Perry and $\mathrm{Hickman}$ (2001) found a wide range of nitrogen content, from $1.0 \%$ to $3.5 \% \mathrm{~N}$, with its average content at a level of $1.3 \% \mathrm{~N}$. In the present study, total nitrogen content, depending on the Magnolia species and year, was in the range of $1.40-2.43 \% \mathrm{~N}$, with its average content of $1.99 \% \mathrm{~N}$. In some species with similar requirements to those of Magnolia, the optimal leaf nitrogen content is reported to be $2.0-3.0 \% \mathrm{~N}$ (K a c p e r s k a et al. 1996), whereas A endekerk (1997) reports the value of $2.44 \% \mathrm{~N}$ for the purple lily magnolia.

Table 2.

Nitrogen, phosphorus, potassium, calcium and magnesium content (\% DW) in the leaves of the investigated species of Magnolia $s p$.

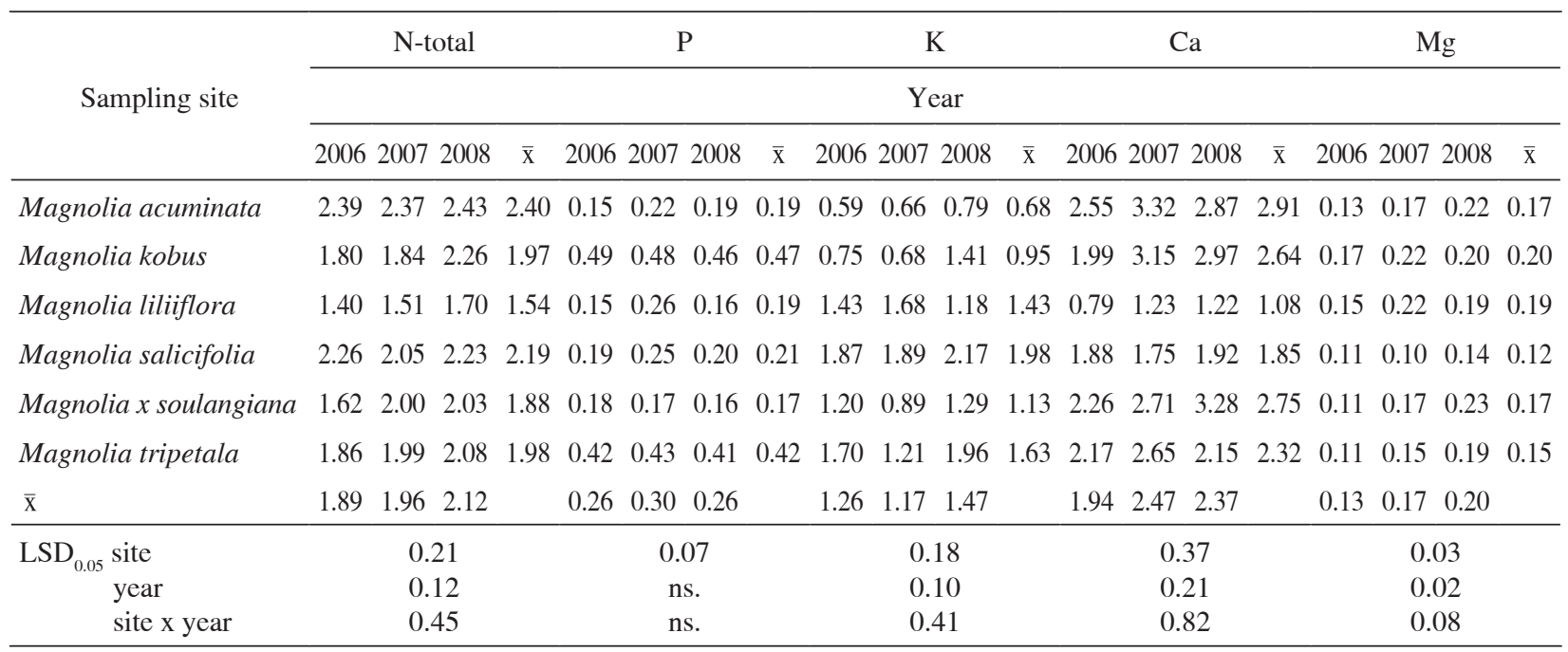

ns. - not significant

The accumulation of macronutrients by perennial ornamental plants is an essential factor reducing the mobility of bioelements in the rhizosphere and may significantly contribute to their reduced leaching to groundwater. This is particularly important in the case of biostabilization of mineral nitrogen and phosphorus (Gilman et al. 2000). Leaf phosphorus content in the Magnolia species under evaluation was in the range of $0.15-0.49 \% \mathrm{P}$. The lowest content of this nutrient was shown in the leaves of Soulange's magnolia (M. $x$ soulangiana $)$ - on average $0.17 \% \mathrm{P}$, whereas the highest one in the Kobushi magnolia (M. kobus) - on average $0.47 \% \mathrm{P}$. According to $\mathrm{Kacpersk}$ a et al. (1996), the range from $0.13 \%$ to $0.30 \% \mathrm{P}$ is assumed to be the optimal one for phosphorus in plants with nutritional requirements similar to those of magnolias. In the present study, leaf phosphorus content is at an average and high level. The obtained results show that among the studied species the tree cucumber $(M . a c u$ minata) and Kobushi magnolia (M. kobus) can be good biostabilizators of nitrogen and phosphorus from the soil environment.

Leaf potassium content in the leaves of the particular species of Magnolia significantly varied. The highest content of this nutrient was found in the leaves of the Japanese willow-leaf magnolia (M. salicifolia) - on average $1.98 \% \mathrm{~K}$, while the lowest one in the tree cucumber (M. acuminata) - on average $0.68 \% \mathrm{~K}$ (Table 2). In the available literature, A e n d e k e rk (1997) reports that the value of $2.24 \% \mathrm{~K}$ is he optimal level of potassium for magnolias, while K a c p e r s k a et al. (1996) give the range from $0.70 \%$ to $1.30 \% \mathrm{~K}$ for plants with similar requirements to those of Magnolia. Hence, leaf potassium content in the Kobushi magnolia and tree cucumber should be assessed as low, while in the other species as medium.

Leaf calcium content in the magnolia leaves was in the range of $0.79-3.32 \% \mathrm{Ca}$. The highest content of this nutrient was found in the leaves of the tree cucumber (M. acuminata) - on average $2.92 \% \mathrm{Ca}$, 
whereas the lowest one in the leaves of the purple lily magnolia ( $M$. liliiflora $)-1.08 \% \mathrm{Ca}$. The obtained results are comparable to the values cited in the literature (K a c perska et al. 1996; A endekerk, 1997; Perry and Hick man, 2001). Significant variation in calcium content between particular sites and years needs to be stressed (Table 2). These differences most probably are an effect of varying weather conditions prevailing during the study period, in particular as far as rainfall distribution is concerned ( $\mathrm{Michałojć}$ and $\mathrm{J}$ arosz 2012). It is known that moisture content in the root environment is one of the main factors determining calcium availability for plants.

\section{CONCLUSIONS}

1. The soil in the location occupied by the purple lily magnolia ( $M$. liliiflora) was found to show the significantly lowest content of phosphorus, potassium and magnesium. The other sites were characterized by an optimal range of $\mathrm{pH}$, high soil phosphorus and magnesium availability as well as medium potassium availability.

2. The optimal content of nitrogen and calcium was found in the leaves of the tree cucumber (M. acuminata), of phosphorus and magnesium in the leaves of the Kobushi magnolia (M. kobus), and of potassium in the leaves of the Japanese willow-leaf magnolia (M. salicifolia).

3. The present study showed a low content of nitrogen and calcium in the leaves of the purple lily magnolia (M. liliiflora), of phosphorus in the leaves of the saucer magnolia (M. $x$ soulangiana), and of potassium in the indicator parts of the tree cucumber ( $M$. acuminata).

4. The study found that among the studied species the tree cucumber (M. acuminata) could be a good biostabilizator of nitrogen, while the Kobushi magnolia (M. kobus) of phosphorus and magnesium.

5. In spite of significant differences in soil availability and clearly varying contents of micronutrients in the indicator parts of the investigated plants, the study found no visual symptoms of nutrient deficit in the studied species of Magnolia.

\section{Acknowledgements}

Research supported by the Ministry of Science and Higher Education of Poland as the part of statutory activities of Department of Cultivation and Fertilization of Horticultural Plants, University of Life Sciences in Lublin.

\section{REFERENCES}

Aendekerk T., 1997. Fertilization guide for nursery crop: adjusting fertilization to meet the crops requirements. Boomteelt Praktijkonderzoek, Nederlanden.

Bruland G.L., Richardson C.J., 2004. A spatially explicit investigation of phosphorus sorption and related soil properties in two riparian wetlands. J. Environ. Qual. 33: 785-794.

Czekalski M., 2007. Magnolie. Wyd. Plantpress, Kraków. (in Polish)

Gilman E.F., Yeager T.H., Kent D., 2000. Fertilizer rate and type impact magnolia and oak growth in sandy landscape soil. J. Arbor. 26 (3): 177-182.

Harris R.W., Paul J.L., Leiser A.T., 1997. Fertilizing woody plants. Agricultural Sciences Leaflet 2958, University of California Cooperative Extension, Richmond, CA.

Hofman H., 2010. Soil pH and plant health in the home garden. Garden Note, 174, Western Australia Department of Agriculture and Food.

Kacperska I., Oświęcimski W., Przeradzki D., Stojanowska J., 1996. Opracowywanie zaleceń nawozowych w ogrodnictwie. Wyd. SGGW, Warszawa. (in Polish)

Kopinga J., van den Burg J., 1995. Using soil and foliar analysis to diagnose the nutritional status of urban trees. J. Arboric., 21(1): 17-24.

Michałojć Z., Jarosz Z., 2012. Decorative values and the nutritional status of some Magnolia species under the climatic conditions of Lublin. Part 1. Decorative values of the plants. Acta Agrobot. 65 (2): 125-132.

Murphy S ., 2009. Soil pH and lime requirements for home grounds plantings. Rutgers New Jersey Agricultural Station, USA.

Nu rzy ń sk i J ., 2003. Nawożenie roślin ogrodniczych. Wyd. AR Lublin. (in Polish)

Ostrowska A., Gawliński S., Szczubiałka Z., 1991. Metody analizy i oceny gleb i roślin. Instytut Ochrony Środowiska, Warszawa. (In Polish)

Perry E., Hickman G., W. 2001. A survey to determine the leaf nitrogen concentrations of 25 landscape tree species. J. Arboric. 27 (3): 152-157.

Petrovic A.M., 1990. The fate of nitrogenous fertilizers applied to turfgrass. J. Environ. Qual. 19(1): 1-14.

Rosen C.J, Bierman P.M., Eliason R.G., 2008. Soil test interpretations and fertilizers management for lawns, turf, gardens and landscape plants. Regents of the University of Minesota.

Whiting D., Card A., Wilson C., Reeder J., 2009. Iron chlorosis. CMG Garden Notes, Colorado State University. 


\section{Walory dekoracyjne oraz stan odżywiania wybranych gatunków Magnolii w warunkach klimatycznych Lublina}

\section{Cz. 2. Ocena stanu odżywiania roślin}

\section{Streszczenie}

Badania przeprowadzono w latach 2006-2008 na terenie Ogrodu Botanicznego UMCS w Lublinie na sześciu gatunkach magnolii. Ocenie poddano glebę oraz liście ze stanowisk magnolii drzewiastej ( $M a-$ gnolia acuminata L.), magnolii japońskiej (Magnolia kobus DC), magnolii purpurowej (Magnolia liliiflora L.), magnolii wierzbolistnej (Magnolia salicifolia Siebold et Zucc. Maxim.), magnolii pośredniej (Magnolia $x$ soulangiana Soul.-Bod.) oraz magnolii parasolowatej (Magnolia tripetala L.). Badane rośliny posadzono w latach 1968-1989 na glebie płowej pochodzenia lessowego. Istotnie najmniejszą zawartość fosforu, potasu i magnezu oraz najniższy odczyn odnotowano w glebie na stanowisku zajmowanym przez magnolię purpurową (M. liliflora). Pozostałe stanowiska charakteryzowały się optymalnym zakresem $\mathrm{pH}$ oraz wysoką zasobnością gleby w fosfor i magnez, a średnią w potas. Odnotowano optymalną zawartość azotu oraz wapnia w liściach magnolii drzewiastej (M. acuminata), fosforu i magnezu w liściach magnolii japońskiej (M. kobus), natomiast potasu $\mathrm{w}$ liściach magnolii wierzbolistnej (M. salicifolia). Wykazano niską zawartość azotu i wapnia w liściach magnolii purpurowej (M. liliflora), fosforu w liściach magnolii posredniej (M. x soulangeana), potasu w częściach wskaźnikowych magnolii drzewiastej (M. acuminata). Stwierdzono, iż spośród badanych gatunków dobrymi biostabilizatorami azotu może być magnolia drzewiasta (M. acuminata), fosforu i magnezu magnolia japońska (M. kobus). Pomimo istotnych różnic w zasobności gleby oraz wyraźnie zróżnicowanej zawartości makroskładników w częściach wskaźnikowych badanych roślin nie stwierdzono żadnych wizualnych objawów deficytu pierwiastków na badanych gatunkach magnolii. 